\title{
'Modernize and Die'? German social democracy and the electoral consequences of the Agenda 2010
}

\author{
Hanna Schwander and Philip Manow \\ Department of Political Science, University of Zurich, Switzerland \\ Correspondence: schwander@ipz.uzh.ch
}

\begin{abstract}
We address the electoral consequences of profound welfare state reforms taking the German Agenda 2010 as an exemplary case. The Agenda is usually perceived as having developed into an electoral disaster for the German Social Democrats (SPD). In this article, we focus on the electoral reactions of directly affected labor market groups in four elections from 1998 to 2009. We combine detailed meso-level information on the regional socioeconomic structure with official elections results. Our findings indicate that the electoral effects of the reform on the group of 'Agenda losers' were limited, while the effect on the German party system and its coalition dynamics are more permanent as the reform helped to entrench a party left to the SPD in the German party system.
\end{abstract}

Key words: labor market reform, political parties, political economy, electoral behavior, unemployment, Germany

JEL classification: I health, education, and welfare

\section{Introduction}

For a long time, the welfare state has been the resource for social democratic parties to mobilize their electorate. But these happy times are long gone since; cutbacks and reforms dominate today. For Social Democracy, this represents a particular challenge: should they adapt the welfare state to the requirements of a post-industrial, knowledge-based economy at the risk of losing the support of their core clientele, that is, blue-collar workers? By continuing to protect the latter's interests, however, social democratic parties would hardly win middleclass votes and would risk remaining confined to the role of a permanent opposition (Kitschelt, 2001; Hopkin, 2004; Karreth et al., 2013). What is more, social democratic parties are also confronted with divided interests within the working class due to labor market 
dualization and insider-outsider divides (Rueda, 2005, 2007; Emmenegger et al., 2012; Häusermann and Schwander, 2012; Schwander, 2013).

In this article, we examine Social Democracy's electoral fate among labor market groups that were directly affected by one of the most profound welfare state reforms in the last decades: the German Agenda 2010. Germany stands out as a paradigmatic case with regard to the extent of the reforms and the consequences for electoral competition. Often, the Agenda 2010 is seen as a prerequisite for Germany's current economic success (Eichhorst et al., 2010; Reisenbichler and Morgan, 2012). At the same time, the reform represents a clear and quite unexpected (see Kitschelt, 2003; Kitschelt and Streeck, 2004) departure from the traditional German social policy model (Kemmerling and Bruttel, 2006; Fleckenstein, 2008; Hassel and Schiller, 2010).

To examine the reform's electoral effects, we employ a different methodological strategy than previous studies. We circumvent the limits of survey data-lack of combined information on socioeconomic status and political behavior plus serious problems of representativeness - by merging detailed data on the socioeconomic situation in Germany's over 400 administrative districts with these districts' official electoral records.

To preview our main findings: we show that the Agenda 2010 had indeed detrimental electoral effects for the German social democratic party (SPD), both directly and indirectly. As a direct effect, Agenda losers over-proportionally withdrew their support from the party. Yet, the indirect effects of the Agenda 2010 on party competition and party configuration are potentially much more lasting. We show that the labor market reforms enabled a new socialist party, die Linke, to establish itself in the German party system because it achieved large vote gains in 'Agenda loser' regions. Moreover, we find that the reforms led many voters to abstain-a trend potentially undermining political legitimacy in the long run.

The article speaks to three strands of literature: First, it contributes to the literature on the politics of dualization by analyzing the electoral consequences of a reform that reduced the privileges of insiders. More broadly, the article contributes to the emerging literature on the electoral consequences of welfare state reforms (for an overview, see Häusermann et al., 2013). Despite common claims about the unpopularity of welfare state reforms, studies on their electoral consequences take a cross-country perspective and have yielded inconclusive results (Green-Pedersen, 2001, 2002; Armingeon and Giger, 2008; Giger and Nelson, 2011; Schumacher, 2011; Arndt, 2013). We, by contrast, concentrate on the electoral consequences in one country over several elections among reform losers and winners. This allows us to control for a range of other factors that may have also affected Social Democracy's electoral fate. Third, the article speaks to the literature on party competition and welfare state reforms. In contrast to existing studies, we are not primarily interested in the way party competition conditions welfare state reforms (Kitschelt, 2001; GreenPedersen, 2002), but in how welfare state reforms affect party competition. Germany's party constellation without a nationwide radical left contender for the SPD prior to the Agenda 2010, but its successful establishment in the aftermath of the reform, seems particulary suited for such a study.

Our article is organized as follows: we first give a brief literature review. We then provide the reader with some information on the Agenda 2010, introduced in the legislative term 2002-2005, and identify reform losers and winners. In Section 5, we develop our hypotheses. Section 6 discusses our data and methods and presents our analysis. A short summary concludes. 


\section{The electoral effects of welfare reforms}

Winning elections has become difficult for social democratic parties. Not only is their core constituency declining and are old party loyalities fading (Dalton and Wattenberg, 2000; Oesch, 2008; Bornschier, 2010), social democratic parties are also confronted with strong divides within their electorate, both between middle-class and working-class voters (Kitschelt, 1994; Kriesi, 1998; Gingrich and Häusermann, 2015) and within the working class, which is divided in insiders and outsiders (Rueda, 2007; Emmenegger, et al., 2012; Häusermann and Schwander, 2012). As these voter segments have divergent economic interests in times of intensified distributive conflicts, social democratic parties are torn between these voters groups and must carefully consider whose interest to address primarily.

The literature on labor market dualization makes a clear prediction in this respect: social democratic parties will side with insiders because they are better organized politically and maintain strong party-links-for example, via trade unions (Rueda, 2006, 2007). Outsiders, by contrast, tend to be politically inactive (Rueda, 2007) or to vote for radical parties (King and Rueda, 2008; Marx, 2016). However, one could also argue that due to the increasing number of outsiders, the spread of labor market insecurity within the middle classes (Häusermann et al., 2014) and the high-economic costs of the traditional insider protection model, social democratic parties have electoral incentives to reduce insiders' privileges as this enables them to mobilize the middle class and outsiders (Schwander, 2013). Electoral gains among the middle class, however, might be short-lived only (Karreth, et al., 2013), and the mobilization of outsiders might be difficult due to their low political and economic knowledge and their low interest in politics.

Yet, not only party-voter links might matter, but the strategic configuration of party systems as well. For instance, it has been argued that the left, not being associated by voters with an anti-welfare ideology, will arouse less political resistance when implementing unavoidable cuts (Ross, 2000; see also Kitschelt, 2001). Similarly, Green-Pedersen (2002) argues that left governments do a better job in justifying retrenchment as a cure to existing dysfunctionalities of the welfare state and as a mean to safeguard the welfare state as an institution of solidarity and social justice. Both strategies, however, work primarily if there is no rival party to attack the reform party, as is the case in plurality electoral systems or bloc party systems. This points more generally to the strategic configuration between parties (Kitschelt, 1999, 2001) as a crucial parameter in the electoral politics of welfare reform (Hopkin, 2004; Watson, 2008). Empirically, the growing literature on the relationship between welfare state reforms and electoral politics found equivocal results (GreenPedersen, 2001; Armingeon and Giger, 2008; Giger and Nelson, 2011; Schumacher, 2011; Giger, 2012; Häusermann et al., 2013; Arndt, 2013). So, both theoretically and empirically, the electoral effects of welfare reforms are not clear-cut. Before discussing the distributive implications of the Agenda 2010 for different labor market groups, we briefly describe the content of the reform project focusing on its labor market effects, exemplified in the Hartz Laws.

\section{Defrosting the German Welfare State: The Agenda 2010}

The Agenda 2010 represents a turn away from Germany's traditional 'social insurance' welfare state model (Kemmerling and Bruttel, 2006; Seeleib-Kaiser and Fleckenstein, 2007). 
Four so-called Hartz laws (named after the head of the reform commission, the former human resources officer of Volkswagen, Peter Hartz) increased the activation orientation of the German welfare state and substantially reduced the generosity of unemployment benefits.

The first two Hartz laws, enacted in 2003, strengthened labor market activation and tightened benefit requirements. Once the spell of unemployment lasts longer than 18 months, unemployed are forced to accept any available job, regardless of their original qualification and pay (Koch et al., 2009). A number of smaller policy measures were supposed to make work pay, for example, via the reduction of social contributions on low-paid jobs or via secondary employment ('mini-jobs') or by facilitating small (and smallest) enterprises. The third Hartz law reformed the public employment service in order to improve management and placement of jobseekers.

The last and most controversial Hartz law reformed the structure of the unemployment insurance. Originally, the German unemployment insurance was based on three pillars: unemployed with full contribution records drew generous earning-related unemployment insurance benefits for 32 months. Thereafter, unemployed depended on the less generous but still earning-related unemployment assistance for an unlimited period of time. Only those not qualified for unemployment insurance (e.g. marginally employed, those with incomplete contribution records or lone parents) had to rely on the flat-rate social assistance. Hartz IV reduced the drawing period for unemployment benefits drastically from 32 to 12 months for those below the age of 55 and merged unemployment and social assistance to a single flat-rate and means-tested benefit called Arbeitslosengeld II (ALG II; colloquially called Hartz IV). In terms of generosity, ALG II corresponds roughly to the level of the former social assistance benefit and entails much stronger conditionality, but provides better access to placement service and training measures. More than two-thirds of the unemployed today rely on these means-tested benefits (Seeleib-Kaiser and Fleckenstein, 2007; Hassel and Schiller, 2010). Considering that the 'old' welfare system quite generously protected status and qualifications of skilled workers, the tighter job-acceptability conditions, the stricter sanctions and the shorter drawing period for earning-related benefits represent a profound break with the past. Table 1 provides a synopsis of the four reform measures.

Obviously, these reforms cut deep into vested interests. But who exactly lost and who gained from the Agenda project?

\section{Losers and Winners of the Agenda 2010}

The distributive consequences of the reforms were complex. In the wake of the reforms, unemployment decreased steadily to less than $5 \%$ today-cut by more than half compared to the level that had prevailed at the peak of the crisis in 2005. In public debate, the Agenda is commonly perceived as having been crucial for Germany's economic turnaround (among experts, however, this remains controversial). With today around 2.6 million unemployed experts consider a full employment scenario in the foreseeable future possible. If we see full employment as Social Democracy's classical policy promise, ${ }^{1}$ one could expect an approving electoral reaction even of vulnerable labor market groups. Moreover, the reduction in the

1 And Chancellor Schröder put the fight against unemployment indeed repeatedly and publicly at the top of this political agenda during his electoral campaigns. 
Table 1. Overview of Hartz reforms

\begin{tabular}{|c|c|c|}
\hline Reform & Place of action & Change \\
\hline \multirow[t]{2}{*}{ Hartz I (Jan 2003) } & Placement & $\begin{array}{l}\text { - Personal-Service Agentur (temporary work agency), } \\
\text { placement voucher }\end{array}$ \\
\hline & Benefits & $\begin{array}{l}\text { - Tighter definition of suitable work } \\
\text { - More flexible sanction regime }\end{array}$ \\
\hline Hartz II (Jan 2003) & $\begin{array}{l}\text { Increase labor } \\
\text { supply }\end{array}$ & $\begin{array}{l}\text { - Tax/Benefit incentives for low wage and complementary } \\
\text { jobs (Mini-jobs) } \\
\text { - Self-employment (Ich-AG) }\end{array}$ \\
\hline Hartz III (Jan 2004) & Placement & - Organizational reform of Public Employment Service \\
\hline Hartz IV (Jan 2005) & Benefits & $\begin{array}{l}\text { Previously: } \\
\text { - For insiders: up to } 32 \text { months: } 60\left(67^{\dagger}\right) \% \text {, then } 53\left(57^{\dagger}\right) \% \\
\text { unlimited } \\
\text { - For outsiders: social assistance } \\
\text { Merger of unemployment assistance and social assistance to } \\
\text { unemployment benefit II (ALG II, 'Hartz IV') } \\
\text { - For insiders: } 12 \text { months: } 67 \% \text {, then ALG II } \\
\text { - ALG II: flat-rate benefit, } 345 € \text { in West Germany, } 331 € \\
\text { in Eastern Germany (single adult) plus housing costs, } \\
\text { social contributions, access to placement service } \\
\text { - Tighter definition of suitable work }\end{array}$ \\
\hline
\end{tabular}

${ }^{\dagger}$ For claimants with dependent children.

number of jobless people did not—as critiques of the reforms had claimed—come at the cost of undermining the 'normal' segment of the labor market. The number of the 'regularly employed', that is, those subject to mandatory social insurance membership, increased significantly from its low point of slightly more than 26 million in 2005 to 30.5 million in 2015, with 520000 open positions currently. Experts expect 300000 new jobs in 2015 (Berufsforschung, 2015). Being in full-time, nontemporary employment is still the dominant employment form in Germany, for $40 \%$ of those of working age and for $60 \%$ of all in gainful employment (Eichhorst and Tobsch, 2014, p. 10). The major achievement of the Agenda was to reduce the inactivity rate from $24 \%$ in 2002 to $19 \%$ in 2012 (Eichhorst and Tobsch, 2014). In the European Union, the German employment rate today is with $77.5 \%$ second only to the Swedish, while it was at rank 16 only 10 years ago. And although the reform of course produced real losers, some household categories, in particular single mothers, benefitted from higher transfers (Koch et al., 2009, pp. 249-250). By contrast, the rapidly increasing low-wage sector (see Rhein, 2013) is a more worrisome development which may weight strongly in the assessment of the reforms by those potentially affected.

In terms of consequences of the Agenda 2010 for the social democratic electorate, we identify five directly affected groups. First of all, the reform project deprived industrial workers of a large part of their traditional privileges. The German industry, based on the model of diversified qualified production (Streeck, 1992; Hall and Soskice, 2001), requires skilled workers. Protecting skill investments through generous unemployment insurance and strict employment protection was one of the main functions of the traditional German welfare 
state (Manow, 1997; Estévez-Abe et al., 2001; Manow, unpublished data; Streeck and Thelen, 2005). The Agenda reforms significantly violated interests of skilled insider workers and their unions (Hassel and Schiller, 2010). Hence, we consider them clear losers of the reform (contra Palier and Thelen, 2010; Thelen, 2014).

Equally, the reduction and tightened conditionality of unemployment benefits affects the unemployed. Accordingly, the resistance to the Agenda 2010 was particularly pronounced in regions with high unemployment rates such as East Germany, Hamburg, the Ruhr area and the Saarland (Hassel and Schiller, 2010). While the Agenda is associated with substantially lower unemployment on the macro-level, those who remain unemployed receive lower benefits and are subjected to stricter conditionality. This holds, in particular, for long-term unemployed. While they are (on average) less hurt by the reduction of the unemployment benefit as most of them already relied on the much less generous unemployment assistance, they are now subjected to stronger conditionality. For example, ALG II recipients are forced to accept any job (Clasen and Goerne, 2014). The merger of the two tiers brought also a benefit reduction for some groups of long-term unemployed: About $60 \%$ of the former unemployment assistance recipients are financially worse off after the reform while most former social assistant recipients enjoy marginal increases in their benefits (Becker and Hauser, 2006). And although all long-term unemployed now have access to new activation programs and improved placement services-which was previously dependent on the type of benefit and geographical location (Clasen and Goerne, 2014)—we assume that those who remained unemployed, that is, those not put back to work by these programs, belong to the Agenda losers.

The reforms had also negative effects for elderly unemployed. Previously, unemployed over the age of 58 were not expected to return to the labor market. The unemployment scheme was informally (mis-)used as a pre-early retirement scheme (Manow and Seils, 2000). The Agenda 2010 did not only close this exit option by reducing the duration of the unemployment insurance benefit but specifically emphasized the need to rise employment among the elderly. In 2008, the so-called 58-rule, according to which unemployed above this age were not expected to seek employment, was formally abolished.

For low-skilled individuals the reform had ambiguous economic consequences, but given that individuals weight losses were stronger than gains, we count them among the reform losers. With regard to benefits they belong to the winners: Households with an income just below the 'basic security' and those who newly qualify for the basic security scheme (as in contrast to the old social assistance) belong to the reform winners (Koch et al., 2009, pp. 249-250), because of new rules on how to weight own income and wealth against welfare transfers. In contrast, middle-income unemployed are major losers (Trampusch, 2005; Clasen and Goerne, 2014). Similarly, Hassel and Schiller (2010, p. 47) argue that the reform project was most successful in reducing 'hidden' poverty and long-term unemployment, which affects individuals with low-skill endowment most strongly. At the same time, Germany witnesses a rapid expansion of the low-wage sector (Rhein, 2013). This threatens low-wage workers who fear to be replaced by cheaper and more flexible workers.

Taken together, we assume that the social democratic party experiences the strongest electoral setback in the districts particularly negatively affected by the reform, i.e. in regions with a high share of unemployed, long-term unemployed, elderly unemployed, industrial employment and low-skilled individuals in regular employment. 
The literature on party competition and the electoral feasibility of welfare state reforms states that a left rival party prevents a social democratic party to implement substantial welfare state reforms (Ross, 2000; Kitschelt, 2001; Green-Pedersen, 2002). In Germany, by contrast, a radical challenger established itself nationally after (and presumably because of) the SPD's welfare reforms. If the de-alignment between the Agenda losers and the SPD really facilitated the electoral breakthrough of die Linke (the left), we should observe the opposite effect on the outcome of die Linke. This is our party competition hypothesis: the left should gain in the districts with a high share of Agenda losers.

Yet, the Agenda produced also winners. The reforms' biggest winner was the higher income middle class, specifically those with low unemployment risks. The reforms allowed for a substantial shift of welfare state expenses from the unemployment insurance to other purposes with a stronger middle class appeal like-for instance-health, child- or elderlycare. In addition, contributions for the unemployment insurance were lowered from $6.5 \%$ in 2005 to $2.8 \%$ in 2009 as a consequence of the reform. Accordingly, we expect support for the social democratic party to increase with higher shares of Agenda winners in a region.

We turn now to our empirical analysis.

\section{Empirical analysis}

Existing studies on the electoral consequences of welfare state reforms usually rely on survey data. These data, however, suffer from a lack of combined information on socioeconomic status and political behavior. In addition, marginalized social groups are seriously underrepresented in survey data. Given the problems of survey data in the context of our research question, we rely on two alternative data sources: administrative $^{2}$ data provide us with a unique range of socioeconomic indicators at the district level. We match these data with official electoral results from the Federal Returning Officer. ${ }^{3}$ Our data come from 406 administrative districts (Landkreise or Kreisfreie Städte) in four federal elections (1998, 2002, 2005 and 2009), that is, we have $406 \times 4=1636$ observations.

We are interested in whether the social democratic party (/the left) loses (wins) overproportionally in districts with a high share of Agenda losers. Thus, our dependent variable is the SPD's (/the left's) vote share at the district level. Subsequently, we analyze the effect of the Agenda on electoral participation. For disappointed voters, abstention is alternative to vote switching, in particular for socially marginalized groups with limited political knowledge (Brady et al., 1995; Schäfer et al., 2016). Taking turnout into account is important because welfare cutbacks might alienate certain groups from the democratic process (Mahler, 2008; for Germany see Schäfer, 2011). ${ }^{4}$ Yet, it is also important from a strategic, partisan view: if those negatively affected by reforms abstain, the electoral consequences for a party are less severe, and the need to change course apprears less imperative. Put differently: the trade-off between newly gained middle-class votes and lost working class votes is less sharp steep when workers simply abstain.

2 Indikatoren und Karten zur Raumentwicklung (http://www.bbsr.bund.de).

3 Wahlbezirkstatistik des Bundeswahlleiters (http://www.bundeswahlleiter.de).

4 Accordingly, we checked the robustness of our results under the inclusion of vote turnout on state level. Results remained unchained. 
Our independent variables of theoretical interests are the district shares of unemployed, the long-term and the elderly unemployed, industrial workers and the low-skilled in regular employment. We aggregate these groups with a factor analysis to an index of 'Agenda losers'. 'Agenda winners' are measured by the share of high-skilled employment of total employment at the district level. ${ }^{5}$ Since we are interested in the deviation of our groups from the general vote swing (King et al., 2008), we account for the general swing by including the SPD's vote share at state level, or by controlling for the vote share of die Linke or the turnout at state level in models 2 and 3. We also control for the average income at district level. ${ }^{6}$ For more details, see Appendix A.

Two methodological comments are warranted. Since we are interested in the changes of the party's electoral success over time, the models display the interaction between one of our independent variables and an election dummy. The constitutive term for each independent variable measures the electoral success in the 1998 election; the interaction terms measure the success in the subsequent elections. ${ }^{7}$ Coefficients in interaction models cannot be directly interpreted as effects (Brambor et al., 2006; Kam and Franzese, 2007). Differentiation is one possible way to interpret coefficients since 'first derivatives or first differences are effects' (Kam and Franzese, 2007, p. 22). From our regression equation:

$$
Y=\beta o+\beta_{x} X+\beta_{x z} Z X+\beta_{z} Z+e
$$

it follows that the net effect of each of our independent variables is:

$$
d y / d x=\beta_{x}+\beta_{x z} Z
$$

Since the election variable enters as a dummy, adding the constitutive and the interaction effects indicates the net effect of an independent variable in a given election.

Second, our longitudinal design requires us to address serial autocorrelation and unobserved unit-specificities. Fixed effects regression models (FEs) and first difference regression models (FDs) are both able to deal with these methodological challenges. The choice between the two depends on the theoretical interests. FEs express a sustained and long-term effect of a variable while FDs show its immediate effect because after a time lag, the effect is not taken into account anymore. Consequently, FE is more appropriate for events that occur only once in a lifetime and are, therefore, more likely to have a lasting

5 High-skilled individuals have low-unemployment risks (Oesch, 2010; Häusermann et al., 2014) and benefit particulary form the reduction of social contribution to the unemplyoment insurance system. This makes them double reform winners.

6 We experimented with additional control variables such as the share of immigrants among the unemployed, female labor market participation and others. Results did not change in any substantive way.

7 There is a debate whether one always has to include both constitutive terms. Brambor et al. (2006, p. 67) make strong arguments in favor of inclusion because the omission of one of the constitutive terms 'may lead to biased estimates in multiplicative interactions models' (see also Greene, 2003). In Kam and Franzese's point of view, by contrast, including both constitutive terms is only mandatory if both explanatory variables have in independent effect on the dependent variable, that is, when the other explanatory variable equals zero (Kam and Franzese, 2007, p. 16-17). In our case, however, it is plausible to assume that the election year itself has an effect on the electoral outcome of the SPD if unemployment equals zero even if we control for the SPD's share at the state level. We, therefore, include both constitutive terms in the equation. 
effect (Giesselmann and Windzio, 2012, p. 64ff). As the Agenda reforms represent such a unique event and we explicitly assume a lasting impact of the reforms on the relationship between the loser groups and the SPD's electoral outcome, we report the results of FEs with random slopes. The fixed effects control for the unobserved unit-specificities by the subtraction of the unit-specific mean (Snijders and Bosker, 1999), while the random slopes allow the effect of the independent variables to vary over time (Giesselmann and Windzio, 2012). Due to heteroskedasticity in our data all models employ district-clustered standard errors. ${ }^{8}$

Let us now turn to the empirical analysis. Table 2 a displays in Model 1, the estimates for the SPD's relative electoral success among the loser groups at the district level. Models 2 and 3 show the relationship between these groups and the outcome of die Linke and vote abstention, respectively. This allows us to examine our party competition hypothesis: If the dealignment between the Agenda losers and the SPD enabled the electoral breakthrough of die Linke, its electoral performance should be the mirror-image of the SPD's outcome. Vote abstention represents another alternative for disappointed Agenda losers.

We gain two insights from Table 2a. First, we see that the SPD's electoral decline among the Agenda losers did not occur earlier than 2009, presumably because losers realized that the generally positive effect of the reforms on employment prospects had not altered their fate, and it was only then the radical contender of the Social Democrats, die Linke, had firmly established itself in the national party system. In 1998, the SPD won below average in districts with a high share of those labor market groups that later were to suffer by the reforms. But in 2002, the promise to reduce unemployment rates that dominated the SPD's electoral campaign raised hope for an economic upswing and our groups voted in large numbers for the SPD. The positive effect was particularly strong among the unemployment and long-term unemployed while industrial employment und employment among lowskilled individuals had a negative effect on the SPD's outcome in 2002 (results available from the authors). It seems that the industrial workers and the low-skilled individuals, both groups already in employment, considered the SPD's reform plans more skeptically than those outside the labor force. In 2005, the interaction coefficient is still positive but not

8 Because fixed effects model do no allow controlling for the difference between West and East Germany, we run a model that replaces the fixed effects with an East-West dummy (East $=1$, West $=0$ ). Results show that the East-West dummy is significant for the models 1 and 3. To investigate this further, we run the analysis separately for West and East Germany. For the 1998, 2002 and 2009 elections, the results are similar for both parts of Germany: The SPD wins under-proportionally in districts with a high share of the five loser groups in 1998, although the effect is particularly pronounced (and significant) in Eastern Germany. In 2002 and 2005, the party wins over-proportionally. The gain of the SPD's vote share was particularly pronounced in the Agenda loser districts in Eastern Germany, an outcome we attribute not only to SPD Chancellor Schröder's electoral promise to reduce unemployment but also to his immediate support for the victims of the flood that devastated large parts of Eastern Germany in summer 2002, just a few weeks ahead of the elections. We find that the negative effect of the Agenda 2010 in 2009 on the SPD's outcome is largely a Western result, while the SPD won in the Agenda loser districts in Eastern Germany in the same election. Die Linke, by contrast, gained an over-proportional share of votes in loser districts in both parts of Germany, although the positive effect is much stronger in the West. The left already managed to win a disproportionate share of votes in Agenda loser districts in 2005. However, due to the low number of districts in Eastern Germany, the coefficients do not reach significance in the party models (results shown in Supplementary Appendix B). 
Table 2a. The electoral outcomes in Agenda loser districts from 1998 to 2009

\begin{tabular}{|c|c|c|c|}
\hline & $\begin{array}{l}\text { SPD } \\
\text { Model } 1\end{array}$ & $\begin{array}{l}\text { Die Linke } \\
\text { Model } 2\end{array}$ & $\begin{array}{l}\text { Abstention } \\
\text { Model } 3\end{array}$ \\
\hline Agenda losers & $\begin{array}{c}-0.489^{*} \\
(0.21)\end{array}$ & $\begin{array}{l}-0.479 * * \\
(0.15)\end{array}$ & $\begin{array}{c}-0.221 \\
(0.16)\end{array}$ \\
\hline \multicolumn{4}{|l|}{1998 [ref.] } \\
\hline 2002 & $\begin{array}{l}-0.648^{* * *} \\
(0.18)\end{array}$ & $\begin{array}{c}0.078 \\
(0.12)\end{array}$ & $\begin{array}{c}0.322 \\
(0.17)\end{array}$ \\
\hline 2005 & $\begin{array}{l}-1.055^{* * *} \\
(0.32)\end{array}$ & $\begin{array}{l}1.100^{* * * *} \\
(0.24)\end{array}$ & $\begin{array}{l}0.520^{*} \\
(0.26)\end{array}$ \\
\hline 2009 & $\begin{array}{l}-2.434^{* * *} \\
(0.59)\end{array}$ & $\begin{array}{l}2.086^{* * * *} \\
(0.38)\end{array}$ & $\begin{array}{l}1.169^{* * *} \\
(0.44)\end{array}$ \\
\hline \multicolumn{4}{|l|}{$1998 \times$ losers [ref.] } \\
\hline $2002 \times$ losers & $\begin{array}{l}0.427^{* *} \\
(0.13)\end{array}$ & $\begin{array}{c}-0.033 \\
(0.08)\end{array}$ & $\begin{array}{l}0.336 * * \\
(0.10)\end{array}$ \\
\hline $2005 \times$ losers & $\begin{array}{c}0.154 \\
(0.12)\end{array}$ & $\begin{array}{l}0.411^{* * * *} \\
(0.10)\end{array}$ & $\begin{array}{l}0.227^{*} \\
(0.09)\end{array}$ \\
\hline $2009 \times$ losers & $\begin{array}{c}-0.380^{*} \\
(0.15)\end{array}$ & $\begin{array}{l}0.780^{* * * *} \\
(0.13)\end{array}$ & $\begin{array}{c}0.252 \\
(0.13)\end{array}$ \\
\hline SPD state outcome & $\begin{array}{l}0.940^{* * *} \\
(0.03)\end{array}$ & & \\
\hline Die Linke state outcome & & $\begin{array}{l}0.827^{* * * *} \\
(0.04)\end{array}$ & \\
\hline Abstention on state level & & & $\begin{array}{l}0.942^{* * *} \\
(0.03)\end{array}$ \\
\hline Avg. household income & $\begin{array}{l}0.004^{* *} \\
(0.00)\end{array}$ & $\begin{array}{c}-0.002^{*} \\
(0.00)\end{array}$ & $\begin{array}{r}-0.001 \\
(0.00)\end{array}$ \\
\hline Constant & $\begin{array}{r}-2.100 \\
(1.88)\end{array}$ & $\begin{array}{l}2.940 * * \\
(1.03)\end{array}$ & $\begin{array}{c}2.247 \\
(1.45)\end{array}$ \\
\hline$R^{2}$ overall & 0.752 & 0.960 & 0.769 \\
\hline$R^{2}$ & 0.976 & 0.948 & 0.966 \\
\hline Observations & 1608 & 1608 & 1608 \\
\hline Districts & 406 & 406 & 406 \\
\hline
\end{tabular}

Note: Values in parentheses are standard errors; regression with robust standard errors. *Significant at the 0.1 level; * Significant at the 0.05 level; ***Significant at the 0.01 level.

significant anymore. In 2009, then, the interaction turns definitively negative. Taken together the results confirm our first hypothesis that the Agenda 2010 led to a dealignment between the SPD and that part of their core constituency was negatively affected by the reform.

This brings us to our party competition hypothesis. If the hypothesis that the electoral breakthrough of die Linke is a direct consequence of the dealignment of the SPD and the Agenda losers is correct, we would expect die Linke to do well where the SPD fared badly. Model 2 in Table 2a shows exactly this: the social democrats' radical contender wins significantly more votes in the Agenda loser districts in 2009 and 2005, but less in 2002. Vote abstention is another reaction to the Agenda reform by disappointed voters. Model 3 shows 
that abstaining was a frequent response in Agenda loser districts in 2002 and 2005 until die Linke presented itself as a viable party alternative in 2009. While low turnout rates especially among disadvantaged groups are worrisome from a democratic point of view, vote abstention limits the electoral damage for the SPD. As long as disappointed voters abstained, consequences for the SPD were less disastrous as compared to 2009, when disappointed voters turned in large numbers to die Linke.

Table $2 \mathrm{~b}$ shows the same analysis for the winners of the Agenda 2010. As our third hypothesis expects, the Agenda led to a closer alignment between the winners of the reforms and the SPD. Model 1 in Table $2 \mathrm{~b}$ shows that the positive effect of high-skilled employment, our indicator of 'Agenda winners', on the SPD vote share increases over time.' Again, the outcome is inverted for die Linke (Model 2). Unsurprisingly, Model 3 confirms that vote abstention is not prevalent among the winners.

The SPD's electoral fortune among the Agenda winners indicates that the SPD gained votes in middle class districts in 2005 and to a lesser extent also in 2009. Hence, it appears that the Agenda 2010 made the SPD lose their core voters but allowed the party to bind the middle-class voters on a more long-term basis contradicting recent findings by Karreth et al. (2013). Yet, the gains among the middle class were not sufficient to prevent the electoral disaster in 2009 and the nearly $10 \%$ of former SPD voters that turned to die Linke in 2005 (around $7 \%$ in West Germany) were sufficient for this party's electoral breakthrough in the West. $^{10}$

However, given that our analysis remains at the aggregate level, we are well advised to check our regression results with individual-level data on German election studies (Comparative Study of Electoral System; CSES waves 1-3). More precisely, we calculate the predicted probabilities to vote for the SPD, die Linke or to abstain for four labor market groups (the survey does not differ between long- and short-term unemployed) and compare these with the overall probability of voting for the SPD (or die Linke or to abstain). Table 3 reports the general trend as well as the predicted probability to vote for the SPD, die Linke or to abstain for each of the four elections under investigation. These individual-level results confirm the electoral trends among our four groups that we observed at the district level (see Supplementary Appendix C). The turn toward die Linke and away from the SPD is especially pronounced among the unemployed, the older unemployed and the low-skilled employed, and plays out particularly strong in the 2009 election. We note, however, the extremely small number of observations for certain categories of labor market groups-an important reason why we had pursued our analysis on the aggregate level in the first place.

\section{Conclusions}

In the last decade, Germany surprised scholars with profound welfare state and labor market reforms. Previously considered as the epitome of institutional inertia (Kitschelt, 2003;

9 We tested the robustness of this finding with different measurements for Agenda winners: average household income on district level, high-skilled employment in service sector and income $\times$ service sector employment. The results are robust in direction although weaker in size (results not shown).

10 We conducted the analysis separately for East and West Germany. The results for West Germany equal the results for entire Germany. By contrast, the SPD loses predominantly and increasingly due to die Linke in Eastern Germany while voter flows to the CDU are of less importance. 
Table 2b. The electoral outcomes in Agenda winner districts from 1998 to 2009

\begin{tabular}{|c|c|c|c|}
\hline & $\begin{array}{l}\text { SPD } \\
\text { Model } 1\end{array}$ & $\begin{array}{l}\text { Die Linke } \\
\text { Model } 2\end{array}$ & $\begin{array}{l}\text { Abstention } \\
\text { Model } 3\end{array}$ \\
\hline Agenda winners & $\begin{array}{r}-0.022 \\
(0.10)\end{array}$ & $\begin{array}{c}0.109 \\
(0.13)\end{array}$ & $\begin{array}{l}0.407 \cdots * * \\
(0.11)\end{array}$ \\
\hline \multicolumn{4}{|l|}{1998 [ref.] } \\
\hline 2002 & $\begin{array}{l}-1.324^{* * *} \\
(0.21)\end{array}$ & $\begin{array}{l}0.653^{* * *} \\
(0.15)\end{array}$ & $\begin{array}{c}0.382 \\
(0.20)\end{array}$ \\
\hline 2005 & $\begin{array}{l}-1.829^{* * *} \\
(0.31)\end{array}$ & $\begin{array}{l}1.503^{* * * *} \\
(0.29)\end{array}$ & $\begin{array}{l}0.588^{*} \\
(0.30)\end{array}$ \\
\hline 2009 & $\begin{array}{l}-1.911^{* * *} \\
(0.55)\end{array}$ & $\begin{array}{l}2.334^{* * *} \\
(0.48)\end{array}$ & $\begin{array}{l}1.520^{* * *} \\
(0.50)\end{array}$ \\
\hline \multicolumn{4}{|l|}{$1998 \times$ winners [ref.] } \\
\hline $2002 \times$ winners & $\begin{array}{l}0.207^{* * *} \\
(0.03)\end{array}$ & $\begin{array}{c}-0.055^{*} \\
(0.03)\end{array}$ & $\begin{array}{r}-0.055 \\
(0.04)\end{array}$ \\
\hline $2005 \times$ winners & $\begin{array}{l}0.239^{* * * *} \\
(0.04)\end{array}$ & $\begin{array}{c}-0.094 * \\
(0.04)\end{array}$ & $\begin{array}{r}-0.063 \\
(0.04)\end{array}$ \\
\hline $2009 \times$ winners & $\begin{array}{l}0.098^{*} \\
(0.04)\end{array}$ & $\begin{array}{c}-0.086 \\
(0.05)\end{array}$ & $\begin{array}{c}-0.236^{* * *} \\
(0.05)\end{array}$ \\
\hline SPD state outcome & $\begin{array}{l}0.987^{* * *} \\
(0.02)\end{array}$ & & \\
\hline Die Linke state outcome & & $\begin{array}{l}0.914^{* * * *} \\
(0.03)\end{array}$ & \\
\hline Abstention on state level & & & $\begin{array}{l}1.000^{* * * *} \\
(0.02)\end{array}$ \\
\hline Avg. household income & $\begin{array}{l}0.004^{* *} \\
(0.00)\end{array}$ & $\begin{array}{l}-0.004 * * \\
(0.00)\end{array}$ & $\begin{array}{c}-0.002 \\
(0.00)\end{array}$ \\
\hline Constant & $\begin{array}{c}-4.455^{* * *} \\
(1.71)\end{array}$ & $\begin{array}{l}4.947^{* * *} \\
(1.53)\end{array}$ & $\begin{array}{l}1.434 \\
(1.72)\end{array}$ \\
\hline$R^{2}$ overall & 0.771 & 0.968 & 0.783 \\
\hline$R^{2}$ & 0.977 & 0.943 & 0.968 \\
\hline Observations & 1624 & 1624 & 1624 \\
\hline Districts & 406 & 406 & 406 \\
\hline
\end{tabular}

Note: Values in parentheses are standard errors; regression with robust standard errors. *Significant at the 0.1 level; * Significant at the 0.05 level; ***Significant at the 0.01 level.

Kitschelt and Streeck, 2004), the Agenda 2010 represents a clear departure from the traditional German social policy model toward a more activation-based welfare state with a clear flexibilization of the labor market. From the perspective of the insider-outsider theory who see social democratic parties as representatives of insiders, the Agenda 2010 should never have happened and indeed the reforms was met with fierce public resistance. The SPD—as the responsible party—had to endure not only a plummet in public approval and electoral support but also the permanent establishment of a challenger to its left.

In our article, we explore the electoral fallout of the Agenda 2010 among traditional social democratic clienteles. We are especially interested to learn how the SPD fares among those directly affected by the reform, which we identify as the low-skilled, industrial 
Table 3. Predicted probabilities to vote for SPD, die Linke or to abstain

\begin{tabular}{|c|c|c|c|c|c|c|c|c|c|c|c|c|c|c|c|}
\hline & \multicolumn{3}{|c|}{ Baseline model } & \multicolumn{3}{|c|}{ Unemployed } & \multicolumn{3}{|c|}{ Older unemployed } & \multicolumn{3}{|c|}{ Low-skilled employed } & \multicolumn{3}{|c|}{ Industrial workers } \\
\hline & SPD & Die & Abstention & SPD & Die & Abstention & SPD & Die & Abstention & SPD & Die & Abstention & SPD & Die & Abstention \\
\hline & & \multicolumn{2}{|c|}{ Linke } & \multicolumn{3}{|c|}{ Linke } & \multicolumn{3}{|c|}{ Linke } & \multicolumn{3}{|c|}{ Linke } & \multicolumn{3}{|c|}{ Linke } \\
\hline 1998 & 0.43 & 0.05 & 0.06 & 0.48 & 0.07 & 0.25 & 0.53 & 0.01 & 0.03 & 0.48 & 0.05 & 0.07 & 0.45 & 0.05 & 0.04 \\
\hline 2002 & 0.44 & 0.07 & 0.04 & 0.39 & 0.14 & 0.11 & 0.57 & 0.11 & 0.07 & 0.46 & 0.07 & 0.05 & 0.48 & 0.06 & 0.04 \\
\hline 2005 & 0.33 & 0.09 & 0.06 & 0.30 & 0.22 & 0.15 & 0.34 & 0.09 & 0.08 & 0.32 & 0.06 & 0.03 & 0.30 & 0.09 & 0.05 \\
\hline 2009 & 0.23 & 0.11 & 0.14 & 0.14 & 0.21 & 0.47 & 0.20 & 0.17 & 0.21 & 0.23 & 0.14 & 0.13 & 0.40 & n.a. & 0.15 \\
\hline
\end{tabular}

Notes: The models control for age, gender, trade union membership, religiosity, education and income. Excluding those control variables does not change the results significantly. The baseline model is an empty model with only election dummies as independent variables. Source: CSES, waves 1-3 (1998, 2002, 2005, 2009). n.a. = not available.

workers, and the unemployed, in particular the elderly and long-term unemployed. We expected that the SPD loses among these groups because of the Agenda's negative distributive effects for them. At the same time, we link the entrenchment of a new left party, die Linke, in the German party system to the SPD's electoral losses. Although there is growing academic interest in the electoral consequences of welfare state reforms, many of these questions have remained unanswered as of yet due to the lack of adequate data. Existing studies usually rely on survey data, which suffer from a lack of combined information on socioeconomic status and political behavior. In addition, marginalized social groups are seriously underrepresented in survey studies putting their representivity in question. To overcome these problems, we analyze the electoral consequences of the Agenda 2010 at the district level combining detailed information about the social and economic structure of districts with 'hard' data on the electoral outcome. We find our three basic assumptions confirmed by the empirical analysis. First, the Agenda 2010 alienated the SPD from parts of its core constituency. Second, the new party to its left, die Linke, could benefit from this growing enstrangement between voters and the social democratic party. Third, middle-class voters on average rewarded the SPD for its reform efforts (Karreth et al., 2013).

In addition to the reform's direct electoral effects, we also find that the Agenda 2010 had indirect consequences for the electoral prospects of the SPD by altering the party constellation. Mainly as a consequence of the Agenda 2010, the East German and ex-communist Partei des Demokratischen Sozialismus (party of democratic socialism) managed to establish itself firmly in the German party system under the new label die Linke (the left) representing a fetching party alternative for diasppointed SPD voters. In this article, we do not examine the party choice of insiders and outsiders beyond the support for the SPD and the decision to abstain from elections. Yet, it seems reasonable to assume that the Christ-Demokratische Union (Christian democratic union, $\mathrm{CDU}$ ) represents an appealing alternative for disappointed insiders due to its longestablished image as co-founder of the Bismarckian welfare state, which holds up the traditional values of equivalence principle and seniority rules that are so dear to insiders.

When the Christian democrats aborted their 2005-experiment to position themselves even more neoliberal than the 'modernizing' Schröder government in 2009 and returned to the political center, the SPD found itself squeezed between a welfare state-friendly CDU and an orthodox left challenger: this spelled electoral disaster, in particular since the previous election had firmly established die Linke nationally. The 2009 Social Democracy's spectacular fall from voters' grace was, therefore, due to a compound effect in which the Agenda's 
party-system effects and its electoral effects, that is, the growing estrangement between certain labor market groups and the SPD, conspired. The German case shows that the electoral fallout of profound welfare reforms might come with a time lag, and different lag-structures might explain why previous comparative studies could only come up with rather equivocal findings.

\section{Supplementary material}

Supplementary material is available at Socio-Economic Review online.

\section{Funding}

This reserach was generously supported by the Collaborative Reserach Center 597, 'Transformation of the State' at the University of Bremen.

\section{Acknowledgments}

Previous versions of the article have been presented at the University of Duisburg, University of British Columbia, the 2014 Annual meeting of the Swiss Political Science Association in Berne, the 2014 Conference of European Studies in Washington, the Economic Seminar of Nuffield College, Oxford University, the Wissenschaftszentrum Berlin für Sozialforschung and the workshop 'public attitudes on labor market reforms' in Mannheim. We would like to thank Achim Goerres, Tim Vlandas, Marius Busemeyer, Philipp Rehm, Jane Gingrich, David Rueda, Elias Neumann, Bernard Ebbinghaus and the participants of these meetings for their valuable feedback.

\section{References}

Armingeon, K. and Giger, N. (2008) 'Conditional Punishment. A Comparative Analysis of the Electoral Consequences of Welfare State Retrenchment in Oecd Nations, 1980-2003', West European Politics, 31, 558-580.

Arndt, C. (2013) The Electoral Consequences of Third Way Welfare State Reforms: Social Democracy's Transformation and Its Political Costs, Amsterdam, Amsterdam University Press.

Becker, I. and Hauser, R. (2006) Verteilungseffekte Der Hartz-Iv-Reform. Ergebnisse Von Simulationsanalysen, Berlin, Edition Sigma.

Berufsforschung, I. f. A.-u. (2015) 'Iab Prognose 2015 - Der Arbeitsmarkt Bleibt Auf Erfolgskurs', IAB-Kurzbericht, 2015.

Bornschier, S. (2010) Cleavage Politics and the Populist Right: The New Cultural Conflict in Western Europe, Philadelphia, Temple University Press.

Brady, H. E., Verba, S., and Schlozman, K. L. (1995) 'Beyond Ses: A Resource Model of Political Participation', The American Political Science Review, 89, 271-294.

Brambor, T., Clark, W. R., and Golder, M. (2006) 'Understanding Interaction Models: Improving Empirical Analyses', Political Analysis, 14, 63-82.

Clasen, J. and Goerne, A. (2014) 'Germany: Ambivalent Activation'. In Lodemel, I. and Moreira, A. (eds) Activation or Workfare? Governance and the Neo-Liberal Convergence, Oxford, Oxford University Press, pp. 174-202.

Dalton, R. J. and Wattenberg, M. (eds) (2000) Parties Without Partisans. Political Change in Advanced Industrial Democracies, Oxford, Oxford University Press. 
Eichhorst, W., Escudero, V., Marx, P., and Tobin, S. (2010) The Impact of the Crisis on Employment and the Role of Labour Market Institutions, Discussion paper series No. 5320, Forschungsinstitut zur Zukunft der Arbeit.

Eichhorst, W. and Tobsch, V. (2014) Flexible Arbeitswelten, IZA Research Report, 59.

Emmenegger, P., Häusermann, S., Palier, B., and Seeleib-Kaiser, M. (2012) The Age of Dualization. The Changing Face of Inequality in Deindustrializing Societies, New York and Oxford, Oxford University Press.

Estévez-Abe, M., Iversen, T., and Soskice, D. (2001) 'Social Protection and the Formation of Skills: A Reinterpretation of the Welfare State'. In Hall, P. A. and Soskice, D. (eds) Varieties of Capitalism: The Institutional Foundations of Comparative Advantage, Oxford, NY, Oxford University Press, pp. 145-183.

Giesselmann, M. and Windzio, M. (2012) Regressionsmodelle Zur Analyse Von Paneldaten, Berlin, Springer.

Giger, N. (2012) 'Is Social Policy Retrenchment Unpopular? How Welfare Reforms Affect Government Popularity', European Sociological Review, 28, 691-700.

Giger, N. and Nelson, M. (2011) 'The Electoral Consequences of Welfare State Reform. Blame Avoidance or Credit Claiming in the Era of Permanent Austerity?', European Journal of Political Research, 50, 1-23.

Gingrich, J. and Häusermann, S. (2015) 'The Decline of the Working-Class Vote, the Reconfiguration of the Welfare Support Coalition and Consequences for the Welfare State', Journal of European Social Policy, 25, 50-75.

Green-Pedersen, C. (2001) 'Welfare-State Retrenchment in Denmark and the Netherlands, 19821998 - the Role of Party Competition and Party Consensus', Comparative Political Studies, 34, 963-985.

Green-Pedersen, C. (2002) Politics of Justification. Party Competition and Welfare-State Retrenchment in Denmark and the Netherlands from 1982 to 1998, Amsterdam, Amsterdam University Press.

Greene, W. (2003) Econometric Analysis, New Jersey, Prentice Hall.

Hall, P. and Soskice, D. (2001) 'Introduction'. In Hall, P. and Soskice, D. (eds) Varieties of Capitalism: The Institutional Foundations of Comparative Advantage, Oxford, Oxford University Press, pp. 1-68.

Häusermann, S., Kurer, T., and Schwander, H. (2014) 'High-Skilled Outsiders? Labor Market Vulnerability, Education and Welfare State Preferences', Socio-Economic Review, doi:10.1093/ ser/mwu026. Accessed on August 19, 2014.

Häusermann, S., Picot, G., and Geering, D. (2013) 'Rethinking Party Politics and the Welfare State - Recent Advances in the Literature', British Journal of Political Science, 43, 221-240.

Häusermann, S. and Schwander, H. (2012) 'Varieties of Dualization? Labor Market Segmentation and Insider-Outsider Divides across Regimes'. In Emmenegger, P., Häusermann, S., Palier, B., and Seeleib-Kaiser, M. (eds) The Age of Dualization. The Changing Face of Inequality in Deindustrializing Societies, Oxford and New York, Oxford University Press, pp. 27-51.

Hopkin, J. (2004) 'Hard Choices, Mixed Incentives: Globalization, Structural Reform, and the Double Dilemma of European Socialist Parties', Mimeo, London School of Economics.

Kam, C. D. and Franzese, R. J. (2007) Modeling and Interpreting Interactive Hypotheses in Regression Analysis Michigan, University of Michigan Press.

Karreth, J., Polk, J. T., and Allen, C. S. (2013) 'Catchall or Catch and Release? The Electoral Consequences of Social Democratic Parties' March to the Middle in Western Europe', Comparative Political Studies, 46, 791-822.

Kemmerling, A. and Bruttel, O. (2006) 'New Politics' in German Labour Market Policy? The Implications of the Recent Hartz Reforms for the German Welfare State', West European Politics, 29, 90-112. 
King, D. and Rueda, D. (2008) 'Cheap Labor: The New Politics of "Bread and Roses" in Industrial Democracies', Perspectives on Politics, 6, 279-297.

King, G., Rosen, O., Tanner, M., and Wagner, A. F. (2008) 'Ordinary Economic Voting Behavior in the Extraordinary Election of Adolf Hitler', The Journal of Economic History, 68, 951-996.

Kitschelt, H. (1994) The Transformation of the European Social Democracy, New York, Cambridge University Press.

Kitschelt, H. (1999) 'European Social Democracy between Political Economy and Electoral Competition'. In Kitschelt, H., Lange, P., Marks, G., and Stephens, J. (eds) Continuity and Change in Contemporary Capitalism New York, Cambridge University Press, pp. 317-345.

Kitschelt, H. (2001) 'Partisan Competition and Welfare State Retrenchment. When Do Politicians Choose Unpopular Policies?'. In Pierson, P. (ed.) The New Politics of the Welfare State, Oxford, Oxford University Press, pp. 265-302.

Kitschelt, H. (2003) 'Political-Economic Context and Partisan Strategies in the German Federal Elections, 1990-2002', West European Politics, 26, 125-152.

Kitschelt, H. and Streeck, W. (2004) Germany: Beyond the Stable State, London, Routledge.

Koch, S., Kupka, P., and Steinke, J. (2009) Aktivierung, Erwerbstätigkeit Und Teilhabe. Vier Jahre Grundsicherung Für Arbeitssuchende, Bielefeld, Bertelsmann.

Kriesi, H. (1998) 'The Transformation of Cleavages Politics. The 1997 Rokkan Stein Lecture', European Journal of Political Research, 33, 165-185.

Mahler, V. A. (2008) 'Electoral Turnout and Income Redistribution by the State: A CrossNational Analysis of the Developed Democracies', European Journal of Political Research, 47, 161-183.

Manow, P. (1997) Social Insurance and the German Political Economy, MPIfG Discussion Paper No. $97 / 2$.

Manow, P. (2002) Social Protection, Capitalist Production. The Bismarckian Welfare State in the German Political Economy, 1880-1990, Konstanz/Köln, unpublished Habilitationsschrift.

Manow, P. and Seils, E. (2000) 'The Employment Crisis of the German Welfare State', West European Politics, 23, 137-160.

Marx, P. (2016) 'The Insider-Outsider Divide and Economic Voting: Testing a New Theory with German Electoral Data', Socio-Economic Review, 14, 97-118.

Oesch, D. (2008) 'Explaining Workers Support for Right-Wing Populist Parties in Western Europe: Evidence from Austria, Belgium, France, Norway, and Switzerland', International Political Science Review, 29, 349-373.

Oesch, D. (2010) 'What Explains High Unemployment among Low-Skilled Workers? Evidence from 21 OECD Countries', European Journal of Industrial Relations, 16, 39-55.

Palier, B. and Thelen, K. A. (2010) 'Institutionalizing Dualism: Complementaries and Change in France and Germany', Politics \& Societies, 38, 119-148.

Reisenbichler, A. and Morgan, K. J. (2012) 'From "Sick Man" to "Miracle": Explaining the Robustness of the German Labor Market During and after the Financial Crisis 2008-09', Politics \& Society, 40, 549-579.

Rhein, T. (2013) Erwerbseinkommen. Deutsche Geringverdiener Im Europäischen Vergleich, IAB Kurzbericht - Aktuelle Analysen aus dem Institut für Arbeitsmarkt- und Berufsforschung No. 15.

Ross, F. (2000) 'Beyond Left and Right': The New Partisan Politics of Welfare', Governance: An International Journal of Policy and Administration, 13, 155-183.

Rueda, D. (2005) 'Insider-Outsider Politics in Industrialized Democracies: The Challenge to Social Democratic Parties', American Policial Science Review, 99, 61-74.

Rueda, D. (2006) 'Social Democracy and Active Labour-Market Policies: Insiders, Outsiders and the Politics of Employment Protection', British Journal of Political Science, 36, 385-406. 
Rueda, D. (2007) Social Democracy Inside Out. Partisanship and Labor Market Policy in Industrialized Democracies, Oxford: Oxford University Press.

Schäfer, A. (2011) 'Der Nichtwähler Als Durchschnittsbürger: Ist Die Sinkende Wahlbeteiligung Eine Gefahr Für Die Demokratie?'. In Bytzek, E. and Rossteuscher, S. (eds) Der Unbekannte Wähler? Mythen Und Fakten Über Das Wablverhalten Der Deutschen, Frankfurt and New York, Campus.

Schäfer, A., Schwander, H., and Manow, P. (2016) 'Die 'Sozial Auffällige' Nichtwähler: Determinanten Der Wahlenthaltung Bei Der Bundestagswahl 2013'. In Schoen, H. and Weßels, B. (eds) Wablen Und Wähler. Analysen Aus Anlass Der Bundestagswabl 2013, Weisbaden, VS Verlag für Sozialwissenschaften, pp. 21-44.

Schumacher, G. (2011) 'Modernize or Die'? Social Democrats, Welfare State Retrenchment and the Choice between Office and Policy, Amsterdam, University Amsterdam.

Schwander, H. (2013) 'Are Social Democratic Parties Insider Parties? Electoral Strategies of Social Democratic Parties in Western Europe in the Age of Dualisation', paper presented at the 20th Conference of Europeanists, Amsterdam, NL, June 24-27, 2013.

Seeleib-Kaiser, M. and Fleckenstein, T. (2007) 'Discourse, Learning and Welfare State Change', Social Policy \& Administration, 41, 427-543.

Snijders, T. A. and Bosker, R. J. (1999) Multilevel Analysis. An Introduction to Basis and Advanced Multilevel Modelling, London, Sage.

Streeck, W. (1992) Social Institutions and Economic Performance: Studies of Industrial Relations in Advanced Capitalist Economies, London and Beverly Hills, Sage.

Streeck, W. and Thelen, K. (2005) Beyond Continuity: Institutional Change in Advanced Political Economies, Oxford, Oxford University Press.

Thelen, K. (2014) Varieties of Liberalization and the New Politics of Social Solidarity, New York, Cambridge University Press.

Trampusch, C. (2005) 'Sozialpolitik in Post-Hartz Germany', WeltTrends, 47, 77-90.

Watson, S. (2008) 'The Left Divided: Parties, Unions, and the Resolution of Southern Spain's Agrarian Social Question', Politics \& Society, 36, 451-477. 


\section{Appendix A}

Table A1. Operationalization and descriptive information

\begin{tabular}{|c|c|c|c|c|c|}
\hline Variable name & Variable operationalization & Mean & St.Dev. & Min & Max \\
\hline Share of SPD votes & Share of SPD votes at district level & 33.24 & 10.66 & 10.18 & 64.32 \\
\hline SPD state outcome & Vote share of the SPD at state level & 33.22 & 9.32 & 14.60 & 52.40 \\
\hline $\begin{array}{l}\text { Share of die Linke votes } \\
\text { on district level }\end{array}$ & Share of die Linke votes at district level & 7.41 & 8.48 & 0.25 & 37.04 \\
\hline die Linke state outcome & Vote share of die Linke at state level & 7.46 & 8.38 & 0.70 & 32.60 \\
\hline $\begin{array}{l}\text { Abstention on district } \\
\quad \text { level }\end{array}$ & $\begin{array}{l}\text { 1-(valid votes on district level/eligible } \\
\text { votes at district level) } \times 100\end{array}$ & 23.10 & 5.76 & 11.21 & 42.15 \\
\hline Abstention of state level & $\begin{array}{l}\text { 1-(valid votes on state level/eligible votes } \\
\text { at state level) } \times 100\end{array}$ & 22.75 & 5.02 & 15.15 & 39.18 \\
\hline Agenda losers & $\begin{array}{l}\text { Factor analysis of unemployment rate, } \\
\text { share of elderly unemployed, share of } \\
\text { long-term unemployed, share of } \\
\text { industrial employment and share of } \\
\text { low-skilled employed, all at district } \\
\text { level (EV:1.90, retained factors: } 1)\end{array}$ & 0.00 & 1.00 & -1.91 & 3.65 \\
\hline Unemployment rate & $\begin{array}{l}\text { Share of unemployed on civilian } \\
\text { employment at district level, in \% }\end{array}$ & 7.36 & 3.44 & 1.80 & 20.50 \\
\hline $\begin{array}{l}\text { Share of elderly } \\
\text { unemployed }\end{array}$ & $\begin{array}{l}\text { Share of unemployed aged } 55 \text { and older } \\
\text { of total unemployment at district } \\
\text { level, in percentage }\end{array}$ & 16.41 & 5.34 & 6.10 & 44.20 \\
\hline Long-term unemployed & $\begin{array}{l}\text { Share of unemployed, } 1 \text { year and longer, } \\
\text { of total unemployment at district } \\
\text { level, in percentage }\end{array}$ & 32.75 & 7.19 & 9.90 & 59.20 \\
\hline Industrial employment & $\begin{array}{l}\text { Share of employment subject to social } \\
\text { contributions in secondary sector of } \\
\text { total employment subject to social } \\
\text { contributions at district level, in } \\
\text { percentage }\end{array}$ & 29.44 & 8.96 & 6.90 & 64.00 \\
\hline $\begin{array}{l}\text { Low-skilled } \\
\text { employment }\end{array}$ & $\begin{array}{l}\text { Share of low-skilled employed subject to } \\
\text { social contributions of total } \\
\text { employment subject to social } \\
\text { contributions at district level, in } \\
\text { percentage }\end{array}$ & 28.65 & 4.97 & 13.50 & 42.00 \\
\hline Agenda winners & $\begin{array}{l}\text { High-skilled employment: Share of } \\
\text { employees with tertiary degree per } \\
100 \text { inhabitants at district level, in } \\
\text { percentage }\end{array}$ & 3.77 & 3.05 & 0.50 & 29.70 \\
\hline Arg. Household income & $\begin{array}{l}\text { Disposable income per household in } \\
\text { Euro per inhabitant, at district level }\end{array}$ & 1402.4 & 213.2 & 929.1 & 2585 \\
\hline
\end{tabular}

